\title{
Henryk OWCZAREK
}

Krajowa Izba Diagnostów Laboratoryjnych

\section{Anna AUGUSTYNOWICZ}

Centrum Medyczne Kształcenia Podyplomowego, WUM Warszwa

\section{Rola badań diagnostyki laboratoryjnej w procesie leczenia}

\author{
„Zapobieganie jest ważniejsze niż leczenie, \\ ponieważ zabezpiecza osobę przed przykrościami i cierpieniem, \\ jakie powoduje choroba oraz zwalnia społeczeństwo od kosztów choroby, \\ które maja wymiar nie tylko ekonomiczny" \\ Karta Praw Pracowników Służby Zdrowia, Watykan
}

27 lipca 2001 r. Sejm Rzeczypospolitej Polskiej uchwalił ustawę o diagnostyce laboratoryjnej (Dz. U. 2001100 poz. 1083 z późn. zm.). Od momentu wejścia jej w życie zostały prawnie unormowane zasady i warunki wykonywania zawodu diagnosty laboratoryjnego a także zasady i warunki wykonywania czynności diagnostyki laboratoryjnej. Ustawą powołany został także samorząd zawodowy diagnostów laboratoryjnych. Jest to najmłodszy samorząd wśród zawodów medycznych, obok samorządu lekarskiego, pielęgniarek i położnych oraz aptekarskiego. Samorząd diagnostów laboratoryjnych zrzesza około 12000 diagnostów laboratoryjnych pracujących w medycznych laboratoriach diagnostycznych w Polsce.

W myśl przepisów ustawy z dnia 30 sierpnia 1991 r. o zakładach opieki zdrowotnej (DZ.U. z 2007r., Nr 14, poz. 89 z późn. zm.) czynności diagnostyki laboratoryjnej są świadczeniami zdrowotnymi. Zgodnie bowiem $\mathrm{z}$ art. 3 omawianej ustawy świadczeniem zdrowotnym są działania służące zachowaniu, przywracaniu i poprawie zdrowia oraz inne działania medyczne wynikające z procesu leczenia lub przepisów odrębnych regulujących zasady ich wykonywania, $\mathrm{w}$ tym związane m.in. $\mathrm{z}$ badaniem diagnostycznym, $\mathrm{w}$ tym analityką medyczną. Podobną definicję świadczenia zdrowotnego zawiera ustawa $\mathrm{z}$ dnia 27 sierpnia 2004 r. (Dz.U. Nr 210, poz. 2135 z późn. zm.) o świadczeniach opieki zdrowotnej finansowanych ze środków publicznych. Świadczeniem zdrowotnym są więc czynności diagnostyki laboratoryjnej, które w myśl przepisów ustawy o diagnostyce laboratoryjnej, obejmują:

- badania laboratoryjne, mające na celu określenie właściwości fizycznych, chemicznych i biologicznych oraz składu płynów ustrojowych, wydzielin, wydalin i tkanek pobranych dla celów profilaktycznych, diagnostycznych i leczniczych lub sanitarno-epidemiologicznych, 
- mikrobiologiczne badania laboratoryjne płynów ustrojowych, wydzielin, wydalin i tkanek pobranych dla celów profilaktycznych, diagnostycznych i leczniczych lub sanitarno-epidemiologicznych,

- działania zmierzające do ustalenia zgodności tkankowej,

- wykonywanie oceny jakości i wartości diagnostycznej badań, o których mowa w pkt 1-3, oraz laboratoryjnej interpretacji i autoryzacji wyniku badań,

- działalność naukową i dydaktyczną prowadzoną w dziedzinie diagnostyki laboratoryjnej.

Dodatkowo celem doprecyzowania określeń ustawowych Uchwałą Nr 61/2004 Krajowej Rady Diagnostów Laboratoryjnych określono słownik do pojęć:

1. wykonywanie oceny jakości badania laboratoryjnego,

2. wykonywanie oceny wartości diagnostycznej badania laboratoryjnego,

3. laboratoryjna interpretacja wyniku badania,

4. autoryzacja wyniku badania laboratoryjnego.

\section{Wykonywanie oceny jakości badania laboratoryjnego}

Jakość badania laboratoryjnego dotyczy cech analitycznych wyniku badania i określa jego wiarygodność i zgodność, w granicach przyjętego zakresu błędu dopuszczalnego. Oceny jakości analitycznej wyniku badania laboratoryjnego dokonuje diagnosta laboratoryjny poprzez właściwą interpretację wyników kontroli wewnątrz - i zewnątrzlaboratoryjnej, opartych o określone zasady prowadzenia kontroli.

\section{Wykonywanie oceny wartości diagnostycznej badania laboratoryjnego}

Ocena wartości diagnostycznej dotyczy cech diagnostycznych wyniku badania i określa prawdopodobieństwo poprawnej oceny stanu zdrowia pacjenta w oparciu o uzyskany wynik laboratoryjny. Oceny wartości diagnostycznej wyniku badania laboratoryjnego dokonuje diagnosta laboratoryjny poprzez znajomość (i właściwy dobór):

1. przydatności poszczególnych badań laboratoryjnych do prognozowania, rozpoznawania i monitorowania stanu zdrowia pacjenta,

2. ograniczeń analitycznych stosowanych metod i testów służących do wykonywania określonych badań laboratoryjnych.

\section{Laboratoryjna interpretacja wyniku badania}

Laboratoryjna interpretacja wyniku badania to zbiór komentarzy i informacji towarzyszących wynikowi badania, wykraczających poza samą wartości liczbową wyrażającą wynik. Laboratoryjna interpretacja wyniku badania zawiera informacje, które pozwalają klinicyście na lepsze wykorzystanie wyniku badania do 
procesu rozpoznawania stanu zdrowia i leczenia pacjenta. Nie obejmuje ze strony diagnosty bezpośredniej oceny stanu pacjenta, rozpoznania i diagnozowania chorób.

\section{Autoryzacja wyniku badania}

Autoryzacja wyniku badania laboratoryjnego stanowi pisemne (podpis i pieczątka) potwierdzenie przez diagnostę laboratoryjnego, że określony wynik uzyskany został po właściwie przeprowadzonej ocenie jakości i wartości diagnostycznej badania, zgodnie z procedurami obowiązującymi w danej jednostce organizacyjnej. Autoryzacja może być rozszerzona o laboratoryjną interpretację wyniku badania, za którą odpowiada podpisujący wynik diagnosta laboratoryjny.

\section{Kto wykonuje badania diagnostyczne w Polsce?}

Do roku $2001 \mathrm{w}$ tym zakresie panował chaos kompetencyjny i organizacyjny. Dopiero ustawa o diagnostyce laboratoryjnej uporządkowała odpowiedzialność za wykonywanie badań diagnostycznych i umiejscowiła badania diagnostyczne w systemie ochrony zdrowia w Polsce. Badania laboratoryjne wykonuje i autoryzuje diagnosta laboratoryjny oraz lekarz posiadający właściwą specjalizacje zgodnie z rozporządzeniem Ministra Zdrowia z dnia 10 sierpnia 2007 r. w sprawie wykazu specjalizacji uprawniających lekarza do samodzielnego wykonywania czynności diagnostyki laboratoryjnej w medycznym laboratorium diagnostycznym, natomiast technik analityki medycznej wykonuje badania laboratoryjne bez prawa do autoryzacji wyniku. Oznacza to, że osoba podpisująca się pod wynikiem badania laboratoryjnego ponosi pełną odpowiedzialność karną, cywilną i zawodową. Do 2002 roku bezpośrednią odpowiedzialność za badania ponosił kierujący na nie lekarz. W rozumieniu art. 17 ust. 1 Konstytucji RP z dnia 2 IV 1997 r. zawód diagnosty laboratoryjnego jest zawodem zaufania publicznego, to znaczy działania władcze w dziedzinie medycznej diagnostyki laboratoryjnej zostały przekazane przez ustawodawcę na samorząd zawodowy diagnostów laboratoryjnych.

Badania laboratoryjne są wykonywane w medycznym laboratorium diagnostycznym, którego definicja, wg normy europejskiej ISO 15189, brzmi: „Jest to laboratorium, które wykonuje biologiczne, mikrobiologiczne, immunologiczne, chemiczne, immuno-hematologiczne, hematologiczne, biofizyczne, cytologiczne lub inne badania materiału pochodzenia ludzkiego, w celu dostarczenia informacji do diagnozowania, profilaktyki oraz leczenia choroby lub oceny stanu zdrowia”. 


\section{Jaka jest funkcja diagnostyki laboratoryjnej w medycynie klinicznej?}

Główną funkcją tej diagnostyki jest stworzenie odpowiedniej możliwości do wykorzystania w medycynie klinicznej wielu odkryć z dziedziny nauk podstawowych. Wyniki badań laboratoryjnych dostarczają informacji pomocnych dla oceny stanu zdrowia badanych, służą do badania stanu fizjologicznego, wczesnego wykrywania i nieustannego rozpoznawania choroby, odzwierciedlają zaburzenia na poziomie komórkowym i subkomórkowym (medycyna profilaktyczna), zanim nastąpią objawy na poziomie narządowym. Jest to ogromna rola diagnostyki laboratoryjnej, która jest bardzo niedoszacowana w polskim systemie ochrony zdrowia. Diagnostyka laboratoryjna w medycynie naprawczej służy także ocenie zaawansowania, monitorowania, ocenie efektywności zastosowanego leczenia, także możliwości wykrycia powikłań skutków ubocznych, do jakich może dojść $\mathrm{w}$ trakcie terapii, kontroli po leczeniu, by zapobiec ewentualnemu powrotowi choroby.

Badania diagnostyczne stanowią najtańsze i najłatwiej dostępne źródło informacji medycznej, cechują się najniższym stopniem zaangażowania personelu medycznego, formą badania jest najczęściej cyfra, która opisuje jednocześnie stan pacjenta, nadaje się do prowadzenia i przetworzenia w komputerowej bazie danych.

Jakie są nakłady finansowe na badania diagnostyczne, na przykładzie Polski, Republiki Czeskiej oraz Hiszpanii. ${ }^{1}$

\begin{tabular}{|l|c|c|c|c|}
\hline \multicolumn{1}{|c|}{ Kraj } & $\begin{array}{c}\text { Liczba } \\
\text { ludności mln }\end{array}$ & PKB/capita w \$ & IVD total mln & IVD/capita Euro \\
\hline Polska & 38,6 & 4737 & 160 & 4,15 \\
\hline Czechy & 10,6 & 5180 & 103 & 9,72 \\
\hline Hiszpania & 40,1 & 11708 & 803 & 20,0 \\
\hline
\end{tabular}

W Republice Czeskiej jest prawie 2,5 razy więcej nakładów na diagnostykę laboratoryjną niż w Polsce, oba te kraje mają podobny PKB. W Hiszpanii, gdzie $\mathrm{w}$ przybliżeniu jest tyle samo mieszkańców co w Polsce, nakłady finansowe na diagnostykę laboratoryjną są 5-krotnie wyższe, co stanowi średnią europejską. W Polsce mamy jeden $\mathrm{z}$ najniższych nakładów finansowych na diagnostykę laboratoryjną w Europie.

Józef L. JakUBIEC „Nakłady na diagnostykę in vitro (IVD) w Unii Europejskiej i w Polsce”, Polityka Zdrowotna nr VII, grudzień 2008/styczeń 2009, str. 25. 


\begin{tabular}{|c|c|c|c|c|c|}
\hline & $\mathbf{2 0 0 3}$ & $\mathbf{2 0 0 4}$ & $\mathbf{2 0 0 5}$ & $\mathbf{2 0 0 6}$ & $\begin{array}{c}\mathbf{2 0 0 7} \\
\text { (prognoza) }\end{array}$ \\
\hline $\begin{array}{c}\text { Wydatki na badania } \\
\text { IVD (\% wydatków na } \\
\text { ochronę zdrowia) }\end{array}$ & $3,4 \%$ & $2,3 \%$ & $2,0 \%$ & $2,1 \%$ & $2,0 \%$ \\
\hline
\end{tabular}

W latach 2003-2007 (dane uzyskane od Izby Producentów i Dystrybutorów Diagnostyki Laboratoryjnej) mimo nakładów zwiększających się na służbę zdrowia, nakłady na diagnostykę laboratoryjną były coraz mniejsze i to jest niepokojące.

W pracach nad koszykiem świadczeń gwarantowanych zostało zgłoszonych, przez Konsultantów Krajowych ok. 1400 świadczeń diagnostycznych.

\section{Lista świadczeń diagnostycznych do koszyka świadczeń gwarantowanych:}

- z diagnostyki laboratoryjnej $\quad \sim 700$

- z medycznej mikrobiologii $\quad \sim 520$

- z toksykologii medycznej $\quad \sim 57$

- $\mathrm{z}$ immunologii medycznej $\quad \sim 50$

- z genetyki medycznej $\quad \sim 51$

- z cytomorfologii medycznej $\quad \sim 30$

Krajowa Rada Diagnostów Laboratoryjnych przyjęła na siebie zadanie opisu struktury świadczeń diagnostycznych. Działania te doprowadzą do:

- ujednolicenia procedur medycznych w diagnostyce laboratoryjnej,

- stworzenie narzędzi do wyceny procedur, do organizacji pracy w MLD (oszacowanie ile procedur - badań może wykonać jeden diagnosta w jednostce czasu, oszacowanie ilu diagnostów potrzebnych jest do wykonania danej ilości badań-procedur),

- powiązanie opisanych procedur z systemem kodowania badań laboratoryjnych.

Niestety mimo ustawowego uznania czynności diagnostyki laboratoryjnej za świadczenia zdrowotne nie są poddane tym samym regulacjom co inne świadczenia zdrowotne. Swoistego rodzaju „dyskryminacja” dotyczy braku kontraktowania badań laboratoryjnych przez Narodowy Fundusz Zdrowia. Problematykę zasad i trybu finansowania ze środków publicznych świadczeń zdrowotnych reguluje wspomniana wyżej ustawa o świadczeniach opieki zdrowotnej finansowanych ze środków publicznych. Finansowanie świadczeń opieki zdrowotnej ze środków publicznych należy do zadań władz publicznych oraz Narodowego Funduszu Zdrowia. Narodowy Fundusz Zdrowia zawiera w trybie przewidzianym przez tę ustawę umowy ze świadczeniodawcami o finansowanie ze środków publicznych świadczeń zdrowotnych. Świadczeniodawcą jest m.in. zakład opieki zdrowotnej. Takie stwierdzenie znajduje swoje odzwierciedlenie w ustawie o zakładach opieki zdrowotnej oraz w ustawie regulującej problematykę finansowania świadczeń ze środków publicznych. 
Reasumując, Narodowy Fundusz Zdrowia może zawrzeć umowę z zakładem opieki zdrowotnej o udzielanie świadczeń zdrowotnych, które mogą być finansowane ze środków publicznych. Medyczne laboratorium diagnostyczne jest zakładem opieki zdrowotnej, jednostką organizacyjną zakładu opieki zdrowotnej lub jednostki badawczo-rozwojowej. Laboratorium podlega wpisowi do rejestru zakładów opieki zdrowotnej prowadzonego na podstawie przepisów ustawy o zakładach opieki zdrowotnej oraz wpisowi do ewidencji laboratoriów prowadzonej przez Krajową Radę Diagnostów Laboratoryjnych. W celu uzyskania wpisu do ewidencji laboratoriów podmiot, który prowadzi laboratorium w terminie 14 dni od dnia uzyskania wpisu do rejestru zakładów opieki zdrowotnej składa wniosek o wpis laboratorium do ewidencji. Na tych samych zasadach następuje wykreślenie laboratorium $\mathrm{z}$ ewidencji.

Nie ma więc żadnych przeszkód prawnych aby Narodowy Fundusz Zdrowia zawierał umowy o wykonywanie badań laboratoryjnych z medycznymi laboratoriami diagnostycznymi. W praktyce jednak ta możliwość nie jest wykorzystana. Jedynie w Polsce badania laboratoryjne nie są bezpośrednio kontraktowane przez podmiot zobowiązany do finansowania świadczeń ze środków publicznych. Koszt badań laboratoryjnych jest wliczony w koszt procedury medycznej. W podstawowej opiece zdrowotnej przekazywana jest stała kwota za zadeklarowanego pacjenta, a w niej uwzględniony jest koszt badania laboratoryjnego. Takie rozwiązanie zwłaszcza w zakresie podstawowej opieki zdrowotnej powoduje wiele szkód. Taka sytuacja skłania lekarzy, zwłaszcza lekarzy podstawowej opieki zdrowotnej do szukania oszczędności w postaci zmniejszenia ilości zlecanych badań diagnostycznych. Oczywistym jest, że przynosi to szkodę dla pacjenta. Około 60\% decyzji medycznych opiera się o informację diagnostyczną IVD przy niewielkich nakładach ${ }^{2}$. Prawidłowa diagnoza lekarska to podstawowy warunek efektywnego leczenia pacjenta. Krajowa Izba Diagnostów Laboratoryjnych zdaje sobie sprawę, że oprócz wyniku badania dla procesu leczenia istotne znaczenie mają także inne ustalenia lekarza, np. uzyskane w wyniku wywiadu.

Często spotykamy się ze stwierdzeniem, że bezpośrednie kontraktowanie badań laboratoryjnych spowoduje, iż nie będziemy leczyć pacjenta, a wyniki badań laboratoryjnych. Niestety przeciwnicy bezpośredniego kontraktowania badań laboratoryjnych nie zdają sobie sprawy z tego, iż dzięki temu będziemy leczyć pacjenta, któremu postawiliśmy prawidłową diagnozę. Nie napawa optymizmem, że liczba wykonywanych rocznie badań diagnostycznych w Polsce w porównaniu do pozostałych krajów Europy wynosi $1 / 5^{3}$. To znaczy, że lekarze często leczą nie mając pewności co do postawionej diagnozy. To z kolei zwiększa

\footnotetext{
European Diagnostic Manufacturers Association, http://www.edma-ivd.be

Józef L. JAKUBIEC „Nakłady na diagnostykę in vitro (IVD) w Unii Europejskiej i w Polsce, „Polityka Zdrowotna” nr VII, grudzień 2008/styczeń 2009, str. 25.
} 
szanse na popełnienie błędu w sztuce medycznej i tym samym prowadzić może do odpowiedzialności prawnej. Czasami lekarze próbują rozwiązać tę sytuację $\mathrm{w}$ inny sposób, tj. wymuszają na pacjencie wykonanie badań we własnym zakresie (za odpłatnością dokonaną przez pacjenta). $Z$ tego powodu rynek badań laboratoryjnych w Polsce opiera się w 30-40\% na badaniach prywatnych (dane szacunkowe z porównania rynku publicznego i niepublicznego na ochronę zdrowia w 2008 r.). Stanowi to ewenement w skali europejskiej, gdzie większość badań finansowana jest ze środków publicznych.

Takie działania są nieetyczne i niezgodne $\mathrm{z}$ obowiązującym prawem. W tym miejscu warto wspomnieć, że zgodnie z art. 15 ustawy o świadczeniach opieki zdrowotnej finansowanych ze środków publicznych ubezpieczonym zapewnia się i finansuje ze środków publicznych na zasadach i w zakresie określonym $\mathrm{w}$ ustawie badania diagnostyczne, $\mathrm{w}$ tym medyczną diagnostykę laboratoryjną. Jednocześnie każdy lekarz zleca stosowne postępowanie diagnostyczne stosownie do stanu zdrowia. I tak np. rozporządzenie Ministra Zdrowia z dnia 20 października 2005 r. (Dz.U. 05.214.1816) w sprawie zakresu zadań lekarza, pielęgniarki i położnej podstawowej opieki zdrowotnej stanowi, iż lekarz podstawowej opieki zdrowotnej, m.in. wykonuje testy lub zleca wykonanie badań dodatkowych, a w szczególności laboratoryjnych i obrazowych.

Na dzień dzisiejszy w Polsce do minimum ograniczono wykonywanie badań laboratoryjnych $\mathrm{w}$ ramach programów profilaktycznych. Poza kilkoma głośnymi programami profilaktycznymi takie badania nie są praktycznie wykonywane. Wskazane wyżej rozporządzenie wskazuje, że lekarz podstawowej opieki zdrowotnej w zakresie działań mających na celu profilaktykę chorób uczestniczy w realizacji programów profilaktycznych. Profilaktyka wymaga nie tylko edukacji pacjenta, ale również wykonywania badań laboratoryjnych. Nie ulega wątpliwości, że właściwa profilaktyka przynosi wymierne korzyści, w tym również finansowe. Im wcześniej wykryta choroba tym mniejsze koszty leczenia i lepsze efekty podjętej terapii.

Kolejny problem to brak jakiegokolwiek nadzoru ze strony władz publicznych nad jakością badań diagnostycznych. Obowiązujące przepisy prawne określają wymagania i standardy obowiązujące w medycznych laboratoriach diagnostycznych. Przestrzeganie tych standardów w praktyce nie podlega żadnej kontroli. Narodowy Fundusz Zdrowia kontraktując świadczenia zdrowotne nie sprawdza, czy medyczne laboratorium diagnostyczne będące podwykonawcą spełnia wymagania określone przez obowiązujące przepisy prawne. Krajowa Izba Diagnostów Laboratoryjnych wielokrotnie zwracała się do Narodowego Funduszu Zdrowia oraz Ministerstwa Zdrowia z prośbą o sprawdzanie czy podwykonawcy podmiotów, $\mathrm{z}$ którymi zawierane są umowy spełniają określone przepisami prawa standardy. Niestety propozycja ta nie spotkała się z zainteresowaniem. Budzi to olbrzymie zdziwienie Krajowej Izby Diagnostów Laboratoryjnych. Podjęcie działań 
kontrolnych jest $\mathrm{w}$ interesie pacjenta. $\mathrm{Z}$ drugiej strony posiadane przez niektóre laboratoria certyfikaty akredytacyjne nie są wykorzystywane do oceny laboratoriów i ich kwalifikacji. W postępowaniach konkursowych, w których uczestniczą laboratoria decydujące znaczenie ma przede wszystkim zaproponowana cena. Jakość nie jest w żaden sposób promowana. Wszystkie te niedociągnięcia zmniejszają bezpieczeństwo pacjenta a jednocześnie sprzyjają tworzeniu czarnego rynku diagnostycznego.

\section{Podsumowanie}

Badania laboratoryjne stanowią integralną część diagnostyki, będącej podstawą postępowania w medycynie naprawczej. Efektywne wykorzystanie diagnostyki laboratoryjnej zależy od właściwego ich doboru, dostępności, jakości ich wykonania, odpowiedniego wykorzystania wyników. KRDL podejmuje działania zmierzające do większej dostępności pacjentów do badań diagnostycznych i sprawdzalności jakości badań laboratoryjnych oraz bezpośredniego kontraktowania badań diagnostycznych przez NFZ. Polska jest jedynym krajem w Europie, gdzie badania nie są bezpośrednio kontraktowane. Sytuacja prawna będzie bardziej czytelna zarówno dla lekarza jak i dla pacjenta. Stagnacja w sektorze diagnostyki w polskim systemie ochrony zdrowia, może wskazywać na ograniczenie liczby badań i zwiększenie zbyt dużego opóźnienia w terapii. Wzrost PKB i nakładów na opiekę zdrowotną, nie przekłada się na jakość leczenia. Utrzymanie tego stanu rzeczy nie podwyższy jakości ochrony zdrowia w Polsce. Trzeba więcej pieniędzy na diagnostykę, bo tylko wtedy lekarze będą mogli podjąć właściwe decyzje medyczne na każdym etapie leczenia.

Wzrost świadomości prawnej społeczeństwa oraz rozwój organizacji pacjentów, może skutkować wzrostem roszczeń pacjentów, w wypadku nie właściwych decyzji medycznych, podejmowanych często bez właściwej oceny diagnostycznej. Zwiększenie nakładów na diagnostykę laboratoryjną zwiększy bezpieczeństwo procesów decyzyjnych, będzie wykrywać potencjał schorzenia w bardzo wczesnej fazie, obniży koszty działań medycznych, podniesie sprawność społeczeństwa i podniesie jakość życia, przy pogarszających się czynnikach demograficznych. 